\title{
Research on Continuity of Ideological and Political Education Environment in Colleges and Its Optimization Ways
}

\author{
Ruiping Qin \\ Department of Ideological and Political Education \\ Harbin University of Science and Technology \\ Harbin, China
}

\author{
Mingmei Zhao \\ Department of Ideological and Political Education \\ Harbin University of Science and Technology \\ Harbin, China
}

\begin{abstract}
Ideological and political education in colleges is complex and long-term. Its implementation is inseparable from the support of ideological and political education environment. Therefore, the ideological and political education environment directly influences the effects of ideological and political education. The creation and improvement of this environment is distinctly important for cohesion and transition of elements in it. Continuity and optimization ways for implementation of this education are analyzed in this paper.
\end{abstract}

Keywords-ideological and political education in colleges; educational environment; continuity; optimization ways

\section{INTRODUCTION}

Human existence is the unification of continuity and noncontinuity, which embody advantages in human life from different perspectives. Continuity of ideological and political education contributes to realization of the goal in ideological and political education. The continuity of ideological and political education was influenced by many factors, especially the environment. President Xi Jinping emphasizes on National Conference on Ideological and Political Work in Universities that the ideological and political education concerns cultivating who, how to cultivate people and cultivate them for whom. It must run through the whole teaching process and realize allround education. Therefore, each ideological and political educator must pay attention to the optimization of environment to keep continuity of ideological and political education.

\section{INTRODUCTION TO ENVIRONMENT OF IDEOLOGICAL AND POLITICAL EDUCATION}

Attentions are paid to ways, methods and contents of ideological and political education. The environment of ideological and political education is not considered, so no consensus has reached on its connotation, but some scholars have made a contribution to it.

\section{A. Elaboration on Environment of Ideological and Political Education}

Zhang Yaocan addresses, "Environment of ideological and political education refers to all external factors that influence ideological and political education, the formation and development of ideology and morality of objects in ideological and political education" ${ }^{(1)}$ That is to say, the environment of ideological and political education refers to all external factors that center on activities of ideological and political education, influencing and restricting the formation of objects' morality.

Environment of ideological and political education consists of external factors that influence ideological and political education. Because ideological and political education consists of varied external factors, the environment becomes integrated entity; different external factors form diversified environment of ideological and political education; constant development contributes to dynamic changes of ideological and political education environment. Therefore, ideological and political education relates to and interacts with environment.

\section{B. Main Contents of Ideological and Political Education Environment in Colleges}

As a subsystem of ideological and political education environment, ideological and political education in colleges refers to all factors that influence the effect of ideological and political education; ideological and political education environment in colleges is one of the elements that form the education process, the objective basis for formation and development of college students' ideology and morality. College students are objects of ideological and political education, so ideological and political education environment has varied components, complex, open and changeable.

First, ideological and political education environment in colleges has varied components, including state (government), theory course of ideological and political education and extracurricular activities, staff of ideological and political work (teachers of ideological and political class, secretary of the party committee at all levels and counselor), college system, media and network, and family that closely relates to colleges and assists ideological and political education environment in colleges. Second, ideological and political education environment in colleges is complicated because of diversified components; various people involved in education also determine the complication of environment; for students,

\footnotetext{
(1) Zhang Yaocan, Modern Ideological and Political Education Disciplinary Theory [M], Wuhan: Hubei People's Press, 2003
} 
complex matters in environment determine the complication of environment. Third, ideological and political education environment in colleges is open without the limitation of time and space, people's communication and communication ways, channel to acquire knowledge information as well as selfknowledge model of college students. Fourth, ideological and political education environment in colleges is changeable. The ever-changing social environment inevitably leads to the change of ideological and political education environment; at the meantime, it changes along with the changes of era; ultimately, it will change with social and economic changes. After understanding connotation, characteristics and components of ideological and political education environment in colleges, we can use it to promote and keep the continuity of ideological and political education.

\section{CONTINUITY OF IDEOLOGICAL AND POLITICAL EDUCATION IN COLLEGES: DEFINITION AND CONNOTATION}

Ideological and political education in colleges is continuous, so students can constantly improve political thought and quality. The continuity is the basic premise of ideological and political education in colleges.

\section{A. Definition of Continuity of Ideological and Political Education in Colleges}

Hegel once said, "Continuity refers to simple self relationship that will not break off because of limit and exclusion". (2) Continuity refers to the uninterrupted relationship that maintains self unification and doesn't exist in the form of one or several nodes separately. Marx dialectical materialism tells us all things experience production, development and extinction; old things die and new things produce. The production, development and extinction of a thing are internal continuous process of a thing; the death of old things and the production of new things are continuous process of things. Both internal continuity of thing and continuity between things embody the continuity of things.

Marxism reveals the nature of continuity and provides scientific methods for us to know continuity. Ideological and political education in colleges is part of ideological and political education. Its effects embody in the continuity of education process and link.

\section{B. Connotation of Ideological and Political Education Environment in Colleges}

1) Analysis on continuity of ideological and political education in colleges: Continuity of ideological and political education in colleges means continuous ideological and political education, including time and space of ideological and political education, and the process that elements and links of ideological and political education interact. Therefore, continuity of ideological and political education in colleges is important to measure the effects of ideological and political education, and check whether the task if fulfilled and whether the teaching objectives are realized in ideological and political

\footnotetext{
(2) Hegel. Volume 1 of Logic [M], Commercial Press, 1966, 195
}

education, at the same time verify the quality of ideological and political education environment. If the ideological and political education is continuous, we can infer the teaching quality and effect of this school are sound; the teaching task can finish and teaching objectives can realize; this college has good environment to promote ideological and political education.

2) Manifestation of continuity of ideological and political education in colleges: First is process. In ideological and political education, educators guide coherently, and college students constantly accept and absorb contents of ideological and political education to connect ideological and political education in earlier and later periods. College students internalize it as a part of lifelong learning. Second is persistence. In ideological and political education, subject, object and environment of education interact to make the education persistent, including educational tasks; for students, ideological and political education during college is persistent. Third is integrity. The continuity of ideological and political education ensures its integration in teaching motivation and objective, task and design, method and means, assessment and acceptance; the learning process of college students about ideological and political education is integral. Persistence, process and integrity of ideological and political education form the continuity of ideological and political education.

\section{INFLUENCE OF IDEOLOGICAL AND POLITICAL \\ EDUCATION ENVIRONMENT IN COLLEGES ON CONTINUITY OF IDEOLOGICAL AND POLITICAL EDUCATION}

The environment and the continuity of ideological and political education supplement each other and have dialectical unification relation. As external element, ideological and political education environment influences process and continuity of ideological and political education; meanwhile, the continuity of ideological and political education constantly improves ideological and political education environment. Scholar Zhang Yaocan observes "Ideological and political education environment and ideological and political education restrict each other. Ideological and political education environment influences activities of ideological and political education". (3) Obviously, the two are inseparable with mutual effect. Ideological and political education environment influences ideological and political education and its continuity through elements in the environment. Positive and negative influences exist at the same time.

\section{A. Influence of State (Government) on Continuity of Ideological and Political Education}

Since the reform and opening up, the construction and development in our country has been unprecedented with difficulties. Party and government propose national development plan and phased development goals, such as the realization of two centenary goals, the realization of Chinese dream and "five-in-one" construction. In order to achieve

\footnotetext{
${ }^{3}$ Zhang Yaocan, Modern Ideological and Political Education Disciplinary Theory [M], Wuhan: Hubei People's Press, 2003
} 
development goals, our country has taken numerous measures and continuously adjusts policies with the changes of situation. With the development of reform and opening up and the establishment and improvement of socialist market economy, the reform enters key stage and contradictions and difficulties are prominent. Most of young students can strengthen their conviction and follow the Party, understand the situation of our country at the present stage, share responsibilities and study hard for state-building. They know they shoulder the historical mission of realizing the great rejuvenation of Chinese nation, form political stand and correctly treat themselves. These college students are important power in promoting ideological and political education in colleges.

At the meantime, some college students change ideology and lack faith in the Party and the government, fail to or are reluctant to correctly understand difficulties of the Party and the state echo with western hostile forces and recklessly advocate "westernization" and "differentiation". Besides, negative effects of market economy, the influence of western politics, the impact of the values of capitalism as well as corruption and degeneration of Party members and cadres make some college students lack faith in the government, appear ideological confusion, lose belief and shake ideal and faith and have distorted values. Some students pursue individualism, money worship and hedonism, lose political orientation and political stand in the increasingly complicated environment, and only consider personal interests instead of the country. The condition of college students severely influences the ideological and political education in colleges and makes the continuity of it more difficult.

\section{B. Influences of Theory Course of Ideological and Political Education and Extracurricular Practice on Continuity of Ideological and Political Education in Colleges}

Theory course of ideological and political education in colleges is the main front of ideological and political education and the important means to guarantee continuity of it, in order to publicize route and policy of the Party and make students receive positive ideological education. At present, setting up, contents, class hour, credit and teaching materials of ideological and political theory course are planned by State Education Commission instead of colleges, embodying the Party and our country attach great importance to it. College students' ideal and faith and political caliber and whether they can accept ideological and political education continuously are determined by ideological and political theory course. On one hand, if adequate attentions are paid to ideological and political theory course, students will have clear life goal and scientific ideal and faith, high political caliber and profession ability, stay the same with the Party and our country and people in from of cardinal issues of right and wrong, protect interests of the country and people and don't haggle over personal gains or losses; on the other hand, if inadequate attentions are paid to ideological and political theory course, some students will lose ideal and faith, seek fame and gain, money worship and hedonism, harm others to benefit themselves, have low political caliber and weak professional ability, lose faith in the country and themselves, repel ideological and political education. Ideological and political education on these students cannot run through college education, let alone the continuity of it.

In order to make ideological and political education become popular among students and achieve good effects, colleges continuously carry out extracurricular practice and form long-term mechanism, such as visit patriotism education base, practice base of ideological and political education, interview and do social survey, organize discussion and case analysis and put on performance. Extracurricular practice stimulates most of the students' enthusiasm in learning ideological and political course and participating in activities of ideological and political education continuously, to make the ideological and political education go on wheels; however, some colleges neglect links and fail to arouse enthusiasm of most of the students, so that students lack interests in learning ideological and political theory. It obstructs ideological and political education obstructed and the continuity of it.

\section{Influence of Ideological and Political Working Staff \\ (Teachers of Ideological and Political Course, Secretary of the Party Committee at All Levels and Counselors) on \\ Ideological and Political Education Environment in Colleges}

The subject of ideological and political education is ideological and political working staff. College teachers teach ideological and political course; secretary of the party committee at all levels are workers of ideological and political education; having close relationship with college students, counselors are works and organizers of ideological and political education. They shoulder arduous task of ideological and political education given by the Party and our country and have the most direct and effective influence on college students.

In the long-term ideological and political education, ideological and political working staffs subtly influence college students. Their quality, educational ability and effects directly influence ideological and political education and its continuity. Practice indicates ideological and political working staff with high quality and strong ability will make ideological and political education smooth and education activities continuous, and vice versa.

\section{Influence of College Rules and Regulations and Media Network on Continuity of Ideological and Political Education}

Sound college rules and regulations guarantees continuity of ideological and political education. It restricts college students and workers of ideological and political education. Attentions of college Party committee and joint efforts of ideological and political workers as well as sound system will make ideological and political education continuous. If not, it's difficult to guarantee continuity of ideological and political education.

Media network (including campus network) has crucial influence on continuity of ideological and political education. In media network, negative contents encourage students to keep forging ahead; negative contents make students decadent. Some students absorb positive energy in media network to 
form correct ideology and improve ideological and political quality. These students are participants and beneficiaries in continuity of ideological and political education. However, some students absorb negative energy in media network and become extreme, shiftless and degenerated, obstructing and destroying continuity of ideological and political education. Therefore, media network has different influence on students and directly influences continuity of ideological and political education.

\section{ANALYSIS ON WAYS TO PROMOTE CONTINUITY OF IDEOLOGICAL AND POLITICAL EDUCATION THROUGH OPTIMIZING IDEOLOGICAL AND POLITICAL EDUCATION ENVIRONMENT}

Optimizing ideological and political education environment means improving and making the best of all elements suitable for the development of continuity of ideological and political education. Elements have positive instead of negative influence to furthest promote the continuity of ideological and political education. The optimization of ideological and political education environment needs elements to serve the continuity of ideological and political education. The ways of optimization are as follows:

First, national adjustment and control should provide policy guarantee for continuity of ideological and political education. The Party and the government grasp the overall situation in ideological and political education, provide policy support and continuously promote theoretical innovation and practice development of ideological and political work and open new situation for its development. Meanwhile, furthest guarantee the dominant and core position of ideological and political education in college education. Colleges shall not ignore or make it become a mere formality. Party committee of all colleges must implement; government must formulate policies to guarantee continuity of ideological and political education as well as provide material and spiritual resources and stimulate favorable elements to create high quality ideological and political education environment, in order to guarantee the ideological and political education is continuous; adhere to problem-orientated principle, make up for deficiencies and seek actual effects, insist reform and innovation, to make the work pertinent and effective; government must guide and supervise ideological and political education, in order to guarantee it is steady and continuous.

Second, strengthen teaching of theory course and practice in ideological and political education, to provide theoretical basis for continuity of ideological and political education. Ideological and political theory course is the main channel of ideological and political education and the premise for continuity of it. Firstly, in provision of ideological and political theory, colleges must implement spirit of the central government, research development background of curriculum provision and determine reform thinking according to actual demands and grasp the objective according to students' thinking characteristic and theoretical characteristics and teaching effects. Secondly, in contents of ideological and political theory course, colleges must base on provisions of the central government and integrate in the newest elements to make contents of it keep pace with the times and realize continuity of ideological and political education in different eras; enrich teaching contents of ideological and political theory course and reserve knowledge for ideological and political education through expanding depth and breadth of knowledge and improving contents and broadening students' horizon. Thirdly, in practical link, extracurricular practice should become the second classroom of ideological and political education. Organize activities about campus culture according to students' characteristics. Organize academic forum and visit patriotism education base and establish longterm practice base for ideological and political education to let students experience new achievements of ideological and political education, so that it will leave impression on students for long and form continuous mechanism of ideological and political education.

Moreover, colleges can constantly improve in and after class and build ideological and political theory course that makes students "sincerely keen on, benefit and don't forget in life" through new ways. Center on the School of Marxism to make courses and ideological and political course have the same direction build platforms through resources on and off campus to form the pattern of "ideology and politics", "education" and "publicity" and strengthen continuity of thoughts, contents, methods and practice of ideological and political education and ten promote its continuity.

Third, improve quality of ideological and political education staff to provide talent support for continuity of ideological and political education. Ideological and political working staffs have made important contributions for the development of higher education. Colleges must broad horizon in selection and pay attention to education and practice and improve incentive mechanism, roundly improve quality of cadres of party and government, communist youth league cadre, teachers of ideological and political theory course and the course of philosophy and social science, counselors and school psychologist, in order to make the team have qualified successors. General Secretary Xi says, it takes good iron to make good products. Teachers are engineers of the human souls. Teachers of ideological and political theory course are major talent resources to keep ideological and political education continuous. In ideological and political education, teachers of ideological and political course teach knowledge and apply methods and organize practice activities and fulfill tasks and research as well as lead the continuity of ideological and political education. The continuity of ideological and political education depends on teachers of ideological and political course. Quality, ability and behavior of them directly influence students' enthusiasm in ideological and political education, the degree of acceptance, the quality of internalization and the period of duration and scientific research of ideological and political education as well as the continuity of it.

Therefore, colleges must improve the mechanism to train teachers of ideological and political course frequently and assess strictly and clarify teachers' educational mission; use information technology such as artificial intelligence and cloud computing to establish resource library of teachers for ideological and political theory course and resource library of teaching and scientific research for ideological and political 
education, share data information, let teachers grasp the newest contents in short period and update knowledge and improve quality; increase input in scientific research of teachers in ideological and political course, encourage innovation research to drive teaching and improve quality and ability of teachers, in order to guarantee continuity of ideological and political education. Besides, secretary of the party committee at all levels, counselors and staff in students' affairs office are important to strengthen continuity of ideological and political education.

Fourth, unite social forces to roundly support the continuity of ideological and political education. When discussing ideological and political education, president $\mathrm{Xi}$ Jinping addresses, "ideological and political education is peopleoriented and must center on, care for and serve students and continuously improve their ideological level, political consciousness, moral character, artistic appreciation and train them into talents with political integrity and professional competence and integrated development". (4) Coordinate relations among school, family and society. Although college environment, family environment and social environment have effects on ideological and political education, they haven't formed effective resultant force. Therefore, schools must communicate with family and society through effective ways and establish long-term mechanism and use favorable resources in family and society. Family, school and society must make joint efforts and fundamentally optimize ideological and political education environment to promote continuity of ideological and political education.

\section{CONCLUSION}

Ideological and political education in colleges is complicated and long-term. The maintenance of its continuity depends on the integration of elements in educational environment. Weak environmental elements will neither guarantee the implementation nor support the continuity of ideological and political education. In Marxism, "the change of environment coincides with human activities, and only can be reasonably regarded as practice of revolution" (5). Marxism affirms people are not passive but active in environment. We will take the initiative to transform, optimize and utilize educational environment, in order to realize continuity of ideological and political education.

\section{REFERENCES}

[1] Zhang Yaocan. Modern Ideological and Political Education [M], Beijing: People's Publishing House, 2006, 64

[2] Hegel. Volume 1 of Logic [M], Commercial Press, 1966, 195

[3] [3]Zhang Yaocan. Modern Ideological and Political Education [M], Beijing: People's Publishing House, 2006, 64

[4] Important Speech of National Conference on Ideological and Political Work in Universities, 2017

[5] Volume 3 of Karl Marx and Frederick Engels [M], Beijing: People's Publishing House, 1995, 264

\footnotetext{
(4) Important Speech of National Conference on Ideological and Political Work in Universities, 2017

${ }^{5}$ Volume 3 of Karl Marx and Frederick Engels [M], Beijing: People's Publishing House, 1995, 264
} 